Loma Linda University

TheScholarsRepository@LLU: Digital Archive of Research, Scholarship \& Creative Works

Loma Linda University Electronic Theses, Dissertations \& Projects

3-1983

\title{
Effects of the Removal of Adherent and Phagocytic Cells on the Spleen Cell Lymphoproliferative Response of Tumor Bearing Mice
}

Aileen M. Hyde

Follow this and additional works at: https://scholarsrepository.llu.edu/etd

Part of the Physiology Commons

\section{Recommended Citation}

Hyde, Aileen M., "Effects of the Removal of Adherent and Phagocytic Cells on the Spleen Cell Lymphoproliferative Response of Tumor Bearing Mice" (1983). Loma Linda University Electronic Theses, Dissertations \& Projects. 638.

https://scholarsrepository.llu.edu/etd/638

This Thesis is brought to you for free and open access by TheScholarsRepository@LLU: Digital Archive of Research, Scholarship \& Creative Works. It has been accepted for inclusion in Loma Linda University Electronic Theses, Dissertations \& Projects by an authorized administrator of TheScholarsRepository@LLU: Digital Archive of Research, Scholarship \& Creative Works. For more information, please contact scholarsrepository@llu.edu. 


\section{Abstract}

EFFECTS OF THE. REMOVAL OF ADHERENT AND PHAGOCYTIC CELLS ON THE SPLEEN CELL LYMPHOPROLIFERATIVE RESPONSE

$$
\begin{gathered}
\text { OF TUMOR-BEARING MICE } \\
\text { by }
\end{gathered}
$$

$$
\text { Aileen M. Hyde }
$$

Cell-mediated immunity was investigated in two $B A L B / C$ mouse tumor systems using the lymphocyte transformation test with phytohemagglutinin as the mitogen. This lymphoproliferative response was quantitated using the Stimulation Index (SI). Spleen cells from mice injected with \#51 cells, a chemically-transformed colon cell line, produced a SI value equal to that of normal mice. There was no evidence for suppressor cell activity in cell mixing experiments in which spleen cells from \#51 cell-injected mice were mixed with spleen cells from normal mice. Following macrophage removal by sephadex G-10 columns and carbonyl iron ingestion, there were no significant changes in the SI values for spleen cells from the \#51 cell-injected mice. In contrast, spleen cells from mice injected with H238 cells, a herpes virus-transformed cell line, had a significantly lower SI value than that of normal mice. Suppressor cell activity was demonstrated in cell mixing experiments in which spleen cells from H238 cell-injected 
mice were mixed with normal spleen cells. Removal of adherent cells from spleen cells from H238 cell-injected mice by Sephadex G-10 columns restored the SI value to that of normal mice. An increased SI value was also seen after removal of phagocytic cells by carbonyl iron. These results suggested that cells with the functional properties of macrophages played an important part in the immunosuppression observed in the H238 tumor system. Comparison of the two macrophage depletion methods suggested that another cell population was also involved in the suppressive effect. 
UNIVERSITY LIBRARY

LOMA LINDA, CALIFORNIA

IOMA IINDA UNIVERSITY

Graduate School

EFFECTS OF THE REMOVAL OF ADHERENT AND PHAGOCYTIC CELLS ON THE SPLEEN CELL LYMPHOPROLIFERATIVE RESPONSE OF TUMOR BEARING MICE

by

Aileen M. Hyde

A Manuscript Submitted in Partial Fulfillment of the Requirements for the Degree Master of Science in Physiology 
Each person whose signature appears below certifies that this manuscript in his opinion is adequate, in scope and quality, in lieu of a thesis for the degree Master of Science.

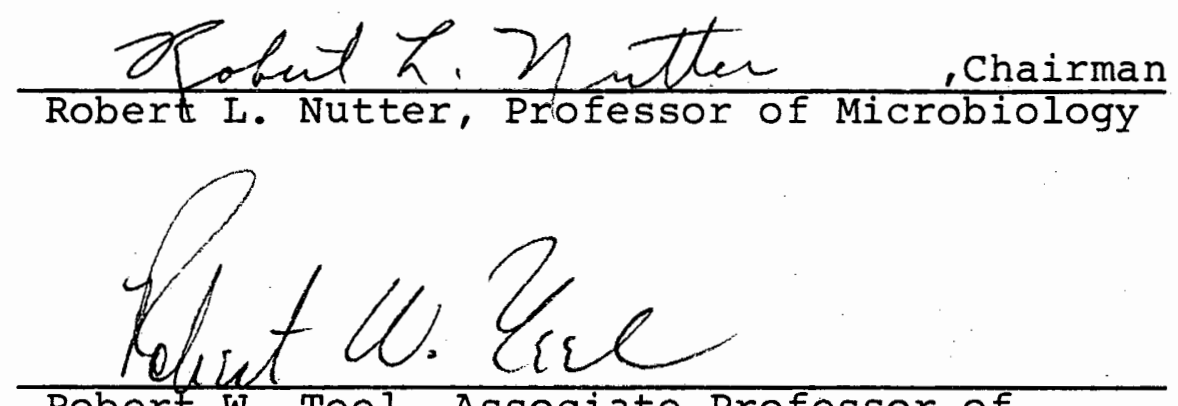

Robert W. Teel, Associate Professor of

Physiology

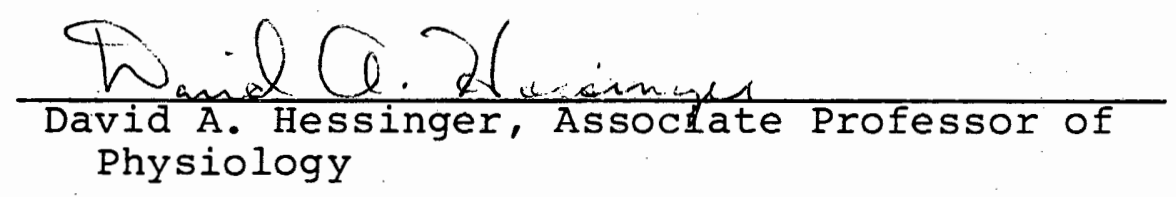




\section{ACKNOWLEDGEMENTS}

I wish to express my appreciation for the help received from the following individuals:

Dr. Robert Nutter, for his encouragement and guidance;

Drs. Robert Teel and David Hessinger, for their helpful suggestions ;

Dr. Daila Gridley, for teaching me many of the techniques used in this project. 


\section{INTRODUCTION}

Macrophages have been shown to serve at least three functions in tumor immunology. Their selective cytotoxicity to neoplastic cells has been demonstrated $(6,20)$. They also have functioned as accessory cells in other host defense mechanisms $(21,60)$. However, in many tumor systems, macrophages actually suppressed the immune response $\quad(1,7,8,10-13,15,17,19,22,23,25-27,29,30,34-36,44-$ $47,50,51,54-57,59,63)$.

The lymphocyte transformation test (LTT) using the mitogen phytohemagglutinin (PHA) (37) has been used to decipher the role of macrophages. It has been demonstrated that PHA is specifically a T-lymphocyte mitogen and that macrophages are essential for this reaction to occur $(14,42,48,49)$. The LTT has been a useful tool for tumor immunologists as many tumor systems have shown a depressed response that correlated with the immune status of the host and host tumor size $(18,22,25,28,41,46,50,52,56,57,59$,$) .$ Using this test, suppressor macrophages have been indirectly demonstrated in many tumor systems. This was usually accomplished by selectively removing these cells which thereby restored lymphoproliferation to normal levels.

Using the LTT as an assay, suppressor macrophages have been associated with tumors transformed chemically $(24,44,46,50,55,59)$, virally $(15,26,27,30,41,57)$, and 
spontaneously $(25,56,59)$. Suppressor macrophages have been demonstrated in spleen cells from tumor-bearing mice (25$27,41,44,46,50,56)$, rats $(22,52,55,57-59)$ and chickens (53). Using similar protocols suppressor macrophages have been identified in blood from cancer patients $(9,29,34,54,63)$ suggesting potential clinical relevance of these animal studies.

The non-specific action of suppressor macrophages has been indicated by similar results obtained in animal and clinical studies when using in vivo tests $(8,11,23,35,36,61)$ and other in vitro immunological tests that measure the function of T-lymphocytes $(1,2,7,10,12,16,17,19,30,33,47$, 51), B-lymphocytes $(1,41,44,45,46,56)$ and natural killer cells (13).

Splenomegaly has been shown to be a characteristic of many tumor-bearing animals $(7,17,24,27,38,41,46,50,62)$. of the tumor systems in which suppressor macrophages have been demonstrated, many also have shown splenomegaly $(7,17,41,46,50,62)$. These include cell lines transformed by viruses $(17,41)$ and chemicals $(7,46,50,62)$.

Our laboratory has been studying two BALB/c mouse tumor systems; one in which tumors are produced by injection of chemically-transformed cells (\#51), and the other in which the tumors are produced as a result of injection of virally-transformed cells (H238) (18,38-40). With both 
systems, tumor-bearing mice showed splenomegaly. The splenomegaly was more pronounced in the H238 system, with the relative spleen weight six times greater than normal (18); whereas in the \#51 system, the spleens were twice the size of normal spleens (40). Furthermore, in the H238 system, there was a depressed lymphoproliferative response to PHA correlating with tumor progression. Spleen stereology studies with $\mathrm{H} 238$ system showed an increase in the compact myeloid tissue, lymphoid nodule reaction centers, and red pulp volume (38). Suppressor macrophages have been demonstrated in another tumor system in which there was also in increased red pulp volume (24). In order to determine if suppressor macrophages were acting in the BALB/C mouse: H238 tumor cell system and in the BALB/C mouse: \#51 tumor cell system, the effects of macrophage removal from spleen cells of tumor-bearing mice on the lymphocyte transformation test were monitored. 
MATERIALS AND METHODS

Mice

BALB/C mice were bred at our institution from mice originally purchased from the Jackson Laboratory (Bar Harbor, ME). The offspring were housed in groups of 6-8 in shoebox-type cages and fed Purina rodent laboratory chow and tap water ad libitum. At the time of injection with tumor. cells, the mice were 18-20 weeks of age.

\section{Tumor Systems}

The H238 tumor was derived from a BALB/C mouse embryo skin cell line (238) transformed by ultraviolet light-irradiated herpes simplex virus type 2 (Savage strain) (3). The \#51 tumor was derived from BALB/c mouse colon cells transformed in vivo by 1,2-dimethylhydrazine (4) and adapted for cell culture in our laboratory. The cells were stored in liquid nitrogen and grown in Dulbecco's medium supplemented with $10 \%$ fetal bovine serum before injection. The mice in each cage were divided into three groups and identified by marking with picric acid. By subcutaneous injection in the right thigh, one group received $1 \times 10^{6}$ H238 cells in $0.3 \mathrm{ml}$ tris-buffered saline (TBS), another group $1.6 \times 10^{5} \# 51$ cells in $0.3 \mathrm{ml}$ TBS, and the control group was injected with $0.3 \mathrm{ml}$ TBS only. At the time of sacrifice seven weeks later, all but two tumor-cell injected 
mice had tumors. These two were excluded from the study. There was no evidence of tumors in the control mice.

\section{Lymphocyte Transformation Test}

For each experimental group, $2 \times 10^{5}$ viable spleen cells were cultured in eight replicate flat-bottom wells of a microtiter plate (Costar, Cambridge, MA). The culture medium consisted of RPMI-1640 supplemented with 20 mM HEPES buffer, $5 \mu \mathrm{M}$ 2-Mercaptoethanol, $10 \%$ heat-inactivated fetal bovine serum $\left(56^{\circ} \mathrm{C}\right.$ for 30 minutes), $100 \mathrm{U} / \mathrm{m}$ penicillin, 4 $\mathrm{mg} / \mathrm{ml}$ Streptomycin, $5 \mu \mathrm{g} / \mathrm{ml}$ Fungizone and $1 \mathrm{U} / \mathrm{ml}$ Mycostatin. The four test wells received $0.28 \mu \mathrm{g}$ of PHA (Burroughs Wellcome Co., Research Triangle Park, NC) in $0.1 \mathrm{ml}$ RPMI-1640, whereas the four control wells received $0.1 \mathrm{ml}$ of RPMI-1640. Five hours prior to culture termination, 1.0 microcurie of ${ }^{3} \mathrm{H}$-thymidine (Research Products International Group, Mt. Prospect, IL, Spec. Act. $49.5 \mathrm{Ci} / \mathrm{mM}$ ) in $0.05 \mathrm{ml}$ RPMI-1640 was added to each well. After 48 hours of culture, the cells were harvested with a multiple sample harvester (Brandel, Gaithersburg, MD) and counted for 2 minutes in a liquid scintillation counter (Beckman, Los Angeles, CA). The Stimulation Index (SI) was calculated from the counts per minute (CPM) according to the following formula:

$$
\text { Stimulation Index }=\frac{\text { Test } C P M-\text { Control CPM }}{\text { Control CPM }}
$$


in which Test CPM represents average values for those wells which received $\mathrm{PHA}$ and Control $\mathrm{CPM}$ represents average values for those wells which did not receive PHA.

Removal of Adherent Cells by Sephadex G-10 Columns

The standard method (32) was adapted to use $12 \mathrm{ml}$ disposable syringes as columns. A sephadex G-10 slurry in $0.85 \%$ saline was added to each syringe to give a $10 \mathrm{ml}$ bed volume. The column was then rinsed with $25 \mathrm{ml}$ of warm RPMI -1640 medium. A $2 \mathrm{ml}$ suspension containing $1 \times 10^{8}$ viable spleen cells was added to the column and rinsed through with $10.0 \mathrm{ml}$ RPMI-1640.

Removal of Phagocytic Cells by Carbonyl Iron Ingestion

Viable spleen cells $\left(1 \times 10^{8}\right)$ from tumor-injected mice were suspended in $10 \mathrm{ml}$ RPMI-1640 containing $100 \mathrm{mg}$ carbonyl iron (Sigma, St. Louis, MO). After one hour of incubation at $37^{\circ} \mathrm{C}$ in a $5 \% \mathrm{CO}_{2}$ incubator, cells containing carbonyl iron and excess carbonyl iron were retained with a 6 1b. magnet and the remaining cells pipetted off. This process was repeated $2-3$ times.

Enrichment of Adherent Cells by Petri Dish Adherence

Viable spleen cells (5 $\times 10^{6}$ ) were suspended in 2 $\mathrm{ml}$ RPMI-1640 and plated into a $60 \mathrm{x} 15 \mathrm{~mm}$ tissue culture dish (Corning Glass Works, Corning, NY). Following a one 
hour incubation at $37^{\circ} \mathrm{C}$ in a $5 \% \mathrm{CO}_{2}$ atmosphere, the nonadherent cells were pipetted off and the adherent cells were removed by scraping with a rubber policeman.

\section{Spleen Cell Differential Counts}

After straining with Wright's stain, a 100-cell differential count was done and the cells were classified as lymphocytes, granulocytes, or macrophages.

\section{Statistical Analysis}

The CPM values obtained from the lymphocyte transformation tests were subjected to the $r$ method (5) of excluding outliers prior to calculation of the means for the stimulation index.

The two-sided student's t-test was used to compare groups. The $p=0.05$ level was chosen as the level of significance. 


\section{RESULTS}

Spleen Cell SI Values

The spleen cells from the H238 cell-injected mice produced lower SI values than their normal counterparts in LTT assays; however, the spleen cell response of the \#51 cell-injected: mice, though lower, was not significantly different from the normal response (Table 1). Comparing the spleen cell differential counts of normal mice with H238 cell-injected mice showed an increase in granulocytes and macrophages $(p=0.05)$ whereas the \#51 cell-injected mice showed an increase only in the granulocyte population $(p=0.05) \quad($ Table 2$)$

\section{Cell Mixing Experiments}

The ability of spleen cells to suppress the lymphoproliferative response of normal cells was examined in cell-mixing experiments. Spleen cells from \#51 cellinjected mice were not suppressive as there were no significant differences in the SI values of various combinations of spleen cells from normal and \#51 cell-injected mice (Figure 1)... In contrast, spleen cells from $\mathrm{H} 238$ cell-injected mice suppressed the SI values of normal spleen cells (Figure 2). The only exception was the mixture containing $90 \%$ cells from normal mice and $10 \%$ cells from H238 cell-injected mice in which the SI value was not significantly different than that of $100 \%$ spleen cells from normal mice. 
Effects of Macrophage Removal and Reconstitution in the H238

System

Spleen cells from H238 cell-injected mice, after passage through the Sephadex G-10 column, produced a SI value equal to that of normal spleen cells (Figure 3). Spleen cell differential counts showed that passage through Sephadex G-10 columns resulted in depletion of macrophages and granulocytes (Table 2). The reconstitution part of the experiment was designed to test for the presence of suppressor macrophages. The hypothesis was that the addition of an enriched macrophage population to macrophagedepleted cells would return the SI value to that of untreated spleen cells from $\mathrm{H} 238$ cell-injected mice. Adding back adherent spleen cells from both normal and H238 cellinjected mice to the Sephadex G-10 nonadherent cells did not drop the SI value to that equal to untreated cells (Figure 3). Spleen cell differential counts showed that there were no significant changes between the untreated population of spleen cells and the adherent spleen cells from both normal and H238 cell-injected mice (Table 2). As shown in Figure 4, carbonyl iron nonphagocytic spleen cells from H238 cellinjected mice had an elevated SI value not statistically different than that of normal cells but not significantly greater than that of the untreated population. Reconstituting the carbonyl iron nonphagocytic cells with normal 
adherent spleen cells did not change the SI value from that of carbonyl iron nonphagocytic cells, whereas adding adherent spleen cells from $\mathrm{H} 238$ cell-injected mice lowered the SI value to that of the untreated population (Figure 4). spleen cell differential counts showed that carbonyl iron treatment resulted in depletion of granulocyte and macrophage populations (Table 2 ).

Effects of Macrophage Removal and Reconstitution in the \#51 System

There were no significant changes in the response of spleen cells from \#51 cell-injected mice following Sephadex G-10 treatment and reconstitution with adherent cells (Figure 5) or following carbonyl iron treatment with subsequent reconstitution with adherent cells (Figure 6). 


\section{DISCUSSION}

Spleen cell differential counts from both groups of tumor-bearing mice showed a decreased percentage of lymphocytes in reference to normal mice. Both groups of tumor-bearing mice demonstrated splenomegaly. This splenomegaly was quantitated by determining the number of cells recovered per spleen. Compared to the number of spleen cells from normal mice, \#51 cell-injected mice showed a three-fold increase and H238 cell-injected mice showed a seven-fold increase in number of cells. Furthermore, changes in spleen morphology in H238 cell-injected mice have been previously characterized by stereology studies in which it was shown that the splenomegaly was not due to increases in splenic connective tissue (38). Thus the decreased percentage of lymphocytes was due to a relative change in percentage of lymphocytes rather than an absolute decrease in total lymphocyte numbers.

The SI values of spleen cells from mice with the chemically-induced tumor, \#51, were not statistically different from those of normal mice. It was not surprising then that there were no differences between the mixtures and starting populations in the cell mixing experiments. Techniques used to remove and add back macrophages had no effect on the SI values produced by spleen cells from \#51 
cell-injected mice. With this assay, there was no evidence for suppressor macrophages in the \#51 system. One cannot be certain, however, that suppression by macrophages was not involved in the \#51 cell-injected tumor system. Since suppressor macrophages have been demonstrated in other chemically-induced tumor systems $(7,46,50,62)$, it might be that the LTT assay system used was not sensitive enough to detect differences in the response of spleen cells from these mice compared with those from normal mice.

In contrast, the SI values produced by spleen cells from mice bearing the virally-induced tumor, H238, was less than that of normal mice. To rule out that this suboptimal response of spleen cells from H238 cell-injected mice was an artifact resulting from a tumor-induced shift in the dose-response curve, PHA titrations with spleen cells from both normal and $\mathrm{H} 238$ cell-injected mice were done. Figure 7 shows that the SI values obtained depicted a bell-shaped curve as established in earlier work (31) and that the optimal concentration of PHA was the same for both sets of spleen cells.

Cell mixing experiments have been used to detect active suppression from cells of tumor-bearing animals $(41,44,46,56)$. Spleen cells from H238 cell-injected mice suppressed the lymphoproliferative response of normal cells (Figure 2). The data suggests that a critical number of 
spleen cells from tumor-bearing animals were necessary for the suppression to occur. Suppression of the SI value of normal cells occurred only when spleen cells from H238 cellinjected mice constituted $25 \%$ and $50 \%$ of the culture; whereas there was no suppression when the culture contained only $10 \%$ spleen cells from $\mathrm{H} 238$ cell-injected mice.

When the spleen cell differential counts of H238 cell-injected mice were compared with those of normal mice, the greatest change was found to be in the increase in percentage of granulocytes in the tumor-bearing mice. A likely candidate for a suppressor cell is a cell type increased in an immunosuppressed tumor-bearing animal. An unexpected finding in this series of experiments was that the techniques chosen for macrophage removal were also effective for granulocyte depletion (Table 2). One can argue against granulocytes acting as suppressor cells in the H238 system by comparing our two tumor systems in which both showed granulocyte infiltration associated with tumor-bearing but immunosuppression only in the H238 system. There have been no reports in the literature of granulocyte-mediated suppression.

Macrophage removal techniques increased the SI values produced by spleen cells from $\mathrm{H} 238$ cell-injected mice. Cells that did not adhere to sephadex G-10 columns produced a higher SI value than cells that did not 
phagocytize carbonyl iron (Table 1). The only significant difference between these groups in the spleen cell differential counts was the percentage of macrophages (Table 2). One interpretation of this data would be that all the macrophages functioning as suppressor cells have been removed in both methods. Sephadex G-10 columns have been shown to remove suppressor $T$ lymphocytes (43). The augmented response of the Sephadex G-10 non-adherent cells might be due to the removal of another type of suppressor cell.

In our reconstitution experiments, adding adherent cells back to cells that have been passed through Sephadex G-10 columns did not reduce the SI value. This protocol has been used by others to confirm that macrophages are functioning as suppressor cells (56). However, these investigators reported an adherent spleen cell population consisting of 95-99\% macrophages. In contrast, we did not achieve an enriched macrophage population from our starting population in any of the three groups of mice (Table 2). With improved techniques yielding a higher percentage of macrophages, we would expect to see the SI values of both spleen cells of normal mice and sephadex G-10 nonadherent spleen cells from $\mathrm{H} 238$ cell-injected mice reduced to that of spleen cells from H238 mice. Spleen cells from H238 cell-injected mice that did not ingest carbonyl iron 
responded quite differently to reconstitution with adherent cells (Figure 4). When normal adherent cells were added, there was no change in the SI value compared to that of the carbonyl iron treated cells; whereas when adherent spleen cells from H238 cell-injected mice were added the SI value was reduced to that equal to the starting population.

Comparison of the SI values of the reconstituted cultures from macrophage-depleted spleen cells of H238 cell-injected mice suggests a specific cellular interaction was needed for immunosuppression to occur. Figure 8 shows that of the four groups only the carbonyl iron treated cells reconstituted with adherent cells from spleens of H238 cell-injected mice produced SI values significantly lower than that of $100 \%$ normal spleen cells. There was no suppression of the carbonyl iron nonphagocytic cells when reconstituted with adherent spleen cells from normal mice; but a significant depression when the same carbonyl iron treated cells were reconstituted with adherent spleen cells from H238 cell-injected mice. This suggests that a tumor-induced adherent suppressor cell played a role in the immunosuppression. Comparing the response of cells not adhering to Sephadex G-10 columns, there was no difference between the SI values produced by cultures reconstituted with adherent cells from normal and $\mathrm{H} 238$ cell-injected mice. A possible explanation for the difference between the 
response of reconstituted cultures from the two macrophage depletion methods is that the cell mediating the suppression was removed by the sephadex G-10 columns. The carbonyl iron method removes phagocytic cells, i.e. granulocytes and macrophages, whereas the sephadex G-10 columns remove adherent cells, i.e. macrophages, and nonspecifically $\mathrm{T}$ suppressor cells (43). Since macrophage removal was common to both methods, $T$ suppressor cells seem to be a likely candidate for the cell interacting with the adherent cells from H238 cell-injected mice to produce the immunosuppression in the H238 system.

The cellular mechanism for the suppression of the Iymphoproliferative response of $\mathrm{H} 238$ cell-injected mice is consistent with tumor-induced adherent cell, presumably a macrophage, interacting with $\mathrm{T}$ suppressor cells. Investigations to test this model are now underway in our laboratory. 
TABLE 1. STIMULATION INDEX OF EXPERIMENTAL GROUPS Results of Five Replicate Experiments

Experimental Group

Baseline:

1. Spleen Cells from normal Mice (N)

2. Spleen Cells from H238 cell-injected Mice (238)

3. Spleen Cells from \#51 cell-injected Mice (\#51)

Cell Mixing Studies:

4. $50 \% \mathrm{~N} \& 50 \mathrm{q} \mathrm{H} 238$

5. $758 \mathrm{~N} \& 258 \mathrm{H} 238$

6. $908 \mathrm{~N} \& 10 \% \mathrm{H} 238$

7. $508 \mathrm{~N} \& 508 \# 51$

8. $758 \mathrm{~N} \& 258 \# 51$

9. $908 \mathrm{~N} \& 108 \# 51$

Macrophage Studies: All wells contain $50 \% \mathrm{~N}$ plus:

10. 508 Carbonyl Fe Nonphagocytic H238 (CF-H238)

11. $408 \mathrm{CF}-\mathrm{H} 238 \& 108$ Normal Adherent

12. 408 CF-H238\& $10 \%$ H238 Adherent

13. 508 Sephadex G-10 Nonadherent H238 (G-H238)

14. 408 G-H238 \& Normal Adherent

15. 408 G-H238\& 108 H238 Adherent

16. 508 Carbonyl Fe Nonphagocytic \#51 (CF-\#51)

17. $408 \mathrm{CF}-\# 51$ \& 108 Normal Adherent

18. $408 \mathrm{CF}-\# 51$ \& 108 \#51 Adherent

19. 508 Sephadex G-10 Nonadherent \#51 (G-\#51)

20. $40 \%$ G-\#51\&10\% Normal Adherent

21. 408 G-\#51\&108 \#51 Adherent
Mean

9. 7

0.8

3. 3

3. 3

5.4

5.4

3.6
5.8

6.3

7. 3

3.5

8. 9

6.9

8.9

6.3

6.6

6.1

4.2
5.4
6.6
Standard Error

2.3

0.1

0.7

1.0

1.3

0.4

2.0

1.7

2.6

1.0

1.8

1.9

1.8

2. 0

1.5

1.3

1.7 
TABLE 2: Spleen Cell Differential counts (mean \pm standard error)

Group

H238 Cell-injected Mice: (H238)

Untreated

Sephadex G-10 Nonadherent (G-H238)

Carbonyl Fe Nonphagocytic (CF-H238)

petri Dish Adherent (H238 Adherent)

\#51 Cell-injected Mice: (\#51)

Untreated

Sephadex G-10 Nonadherent (G-\#51)

Carbonyl $\mathrm{Fe}$ Nonphagocytic (CF-\#51)

Petri Dish Adherent (\#51 Adherent)

Normal:

\section{Untreated}

Petri Dish Adherent (Normal Adherent)

\section{Lymphocytes}

zGranulocytes

\section{Macrophages}

$\begin{array}{lll}45.2 \pm 5.5 & 46.0 \pm 8.3 & 8.8 \pm 3.1 \\ 84.6 \pm 3.9 & 13.6 \pm 3.5 & 1.8 \pm 0.8 \\ 79.2 \pm 7.8 & 20.5 \pm 8.0 & 0.3 \pm 0.3 \\ 55.7 \pm 3.5 & 35.7 \pm 3.5 & 8.6 \pm 0.5\end{array}$

$82.3 \pm 4.1 \quad 16.7 \pm 3.9 \quad 1.0 \pm 0.5$

$99.8 \pm 0.6 \quad 0.2 \pm 0.2 \quad 0 \pm 0$

$98.2 \pm 0.5 \quad 1.8 \pm 0.5 \quad 0 \pm 0$

$93.7 \pm 3.4 \quad 3.0 \pm 1.0 \quad 3.3 \pm 2.4$

$\begin{array}{lll}93.4 \pm 0.9 & 5.3 \pm 1.3 & 1.3 \pm 0.5 \\ 95.3 \pm 3.7 & 3.7 \pm 3.2 & 1.0 \pm 0.6\end{array}$


FIGURE 1: Cell Mixing Experiment Using Spleen Cells from \#51 Cell-injected and Normal Mice

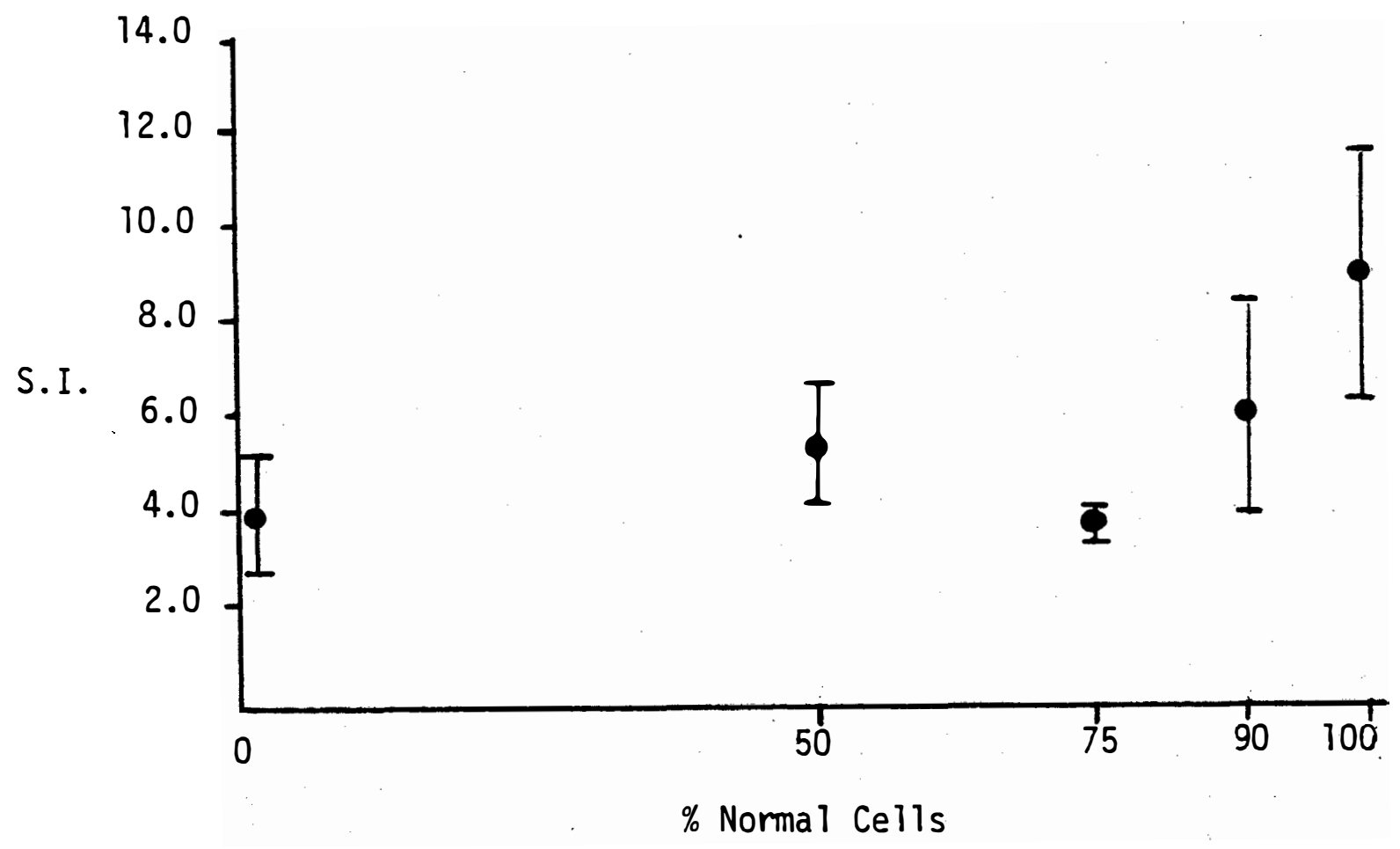


FIGURE 2: Mixing Experiment Using Spleen Cells

from H238 Cell-injected and Normal Mice

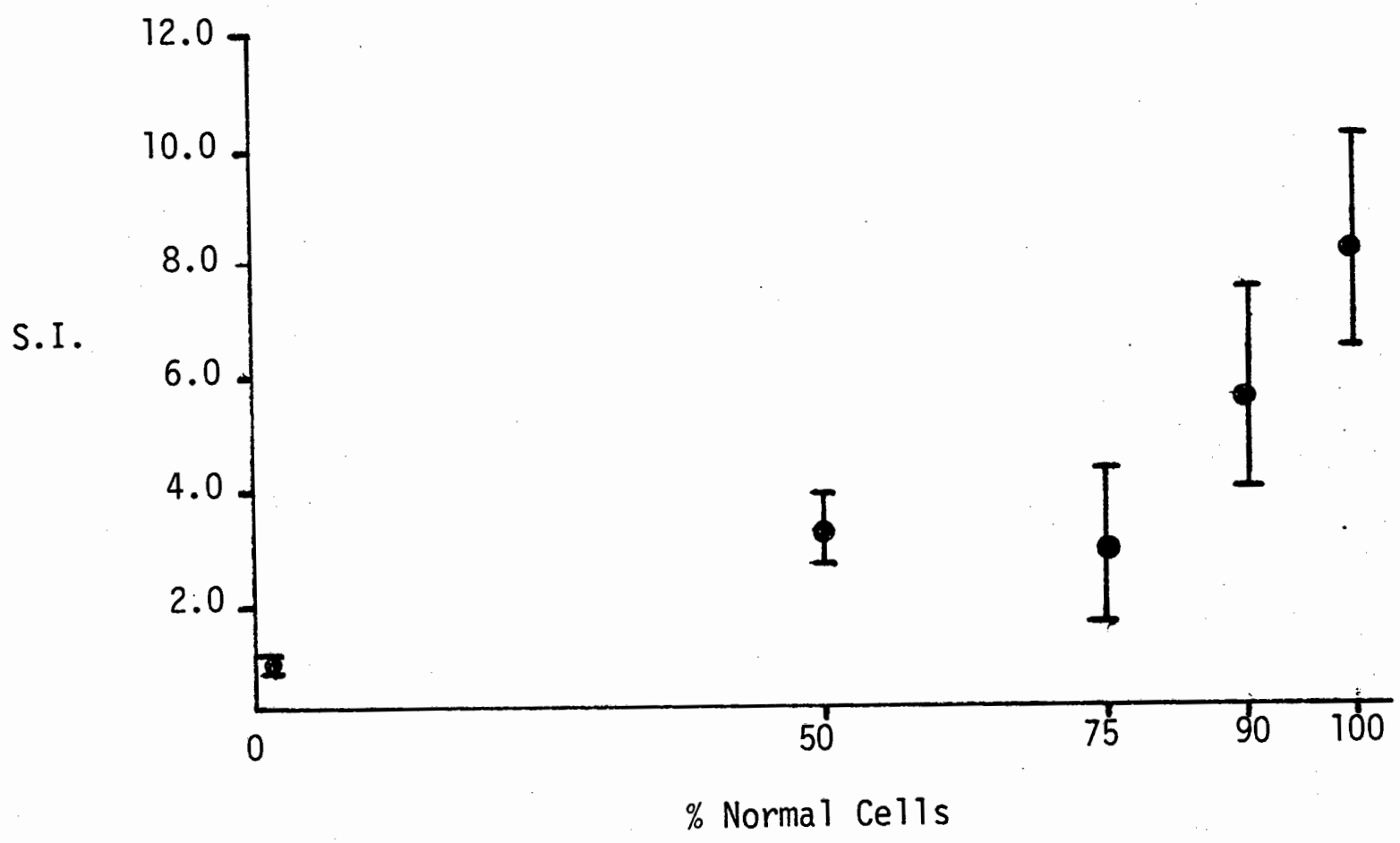


FIGURE 3: Effects of Sephadex G-10 Treatment and Reconstitution with Adherent Cells on Spleen Cell Response to PHA Stimulation in the H238 System

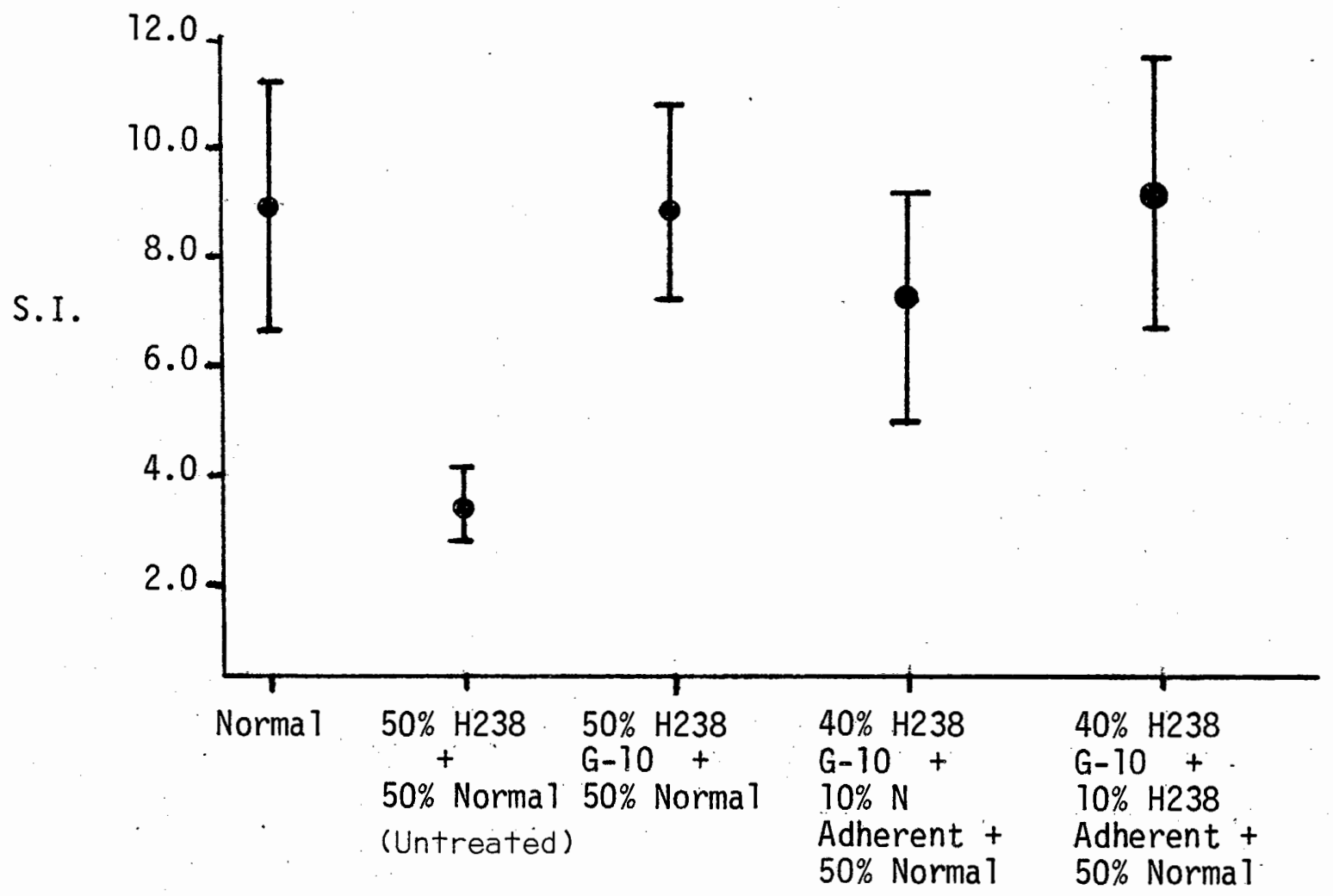


FIGURE 4: Effect of Carbonyl Iron Treatment and Reconstitution with Adherent Cells on Spleen Cell Response to PHA Stimulation in the H238 System

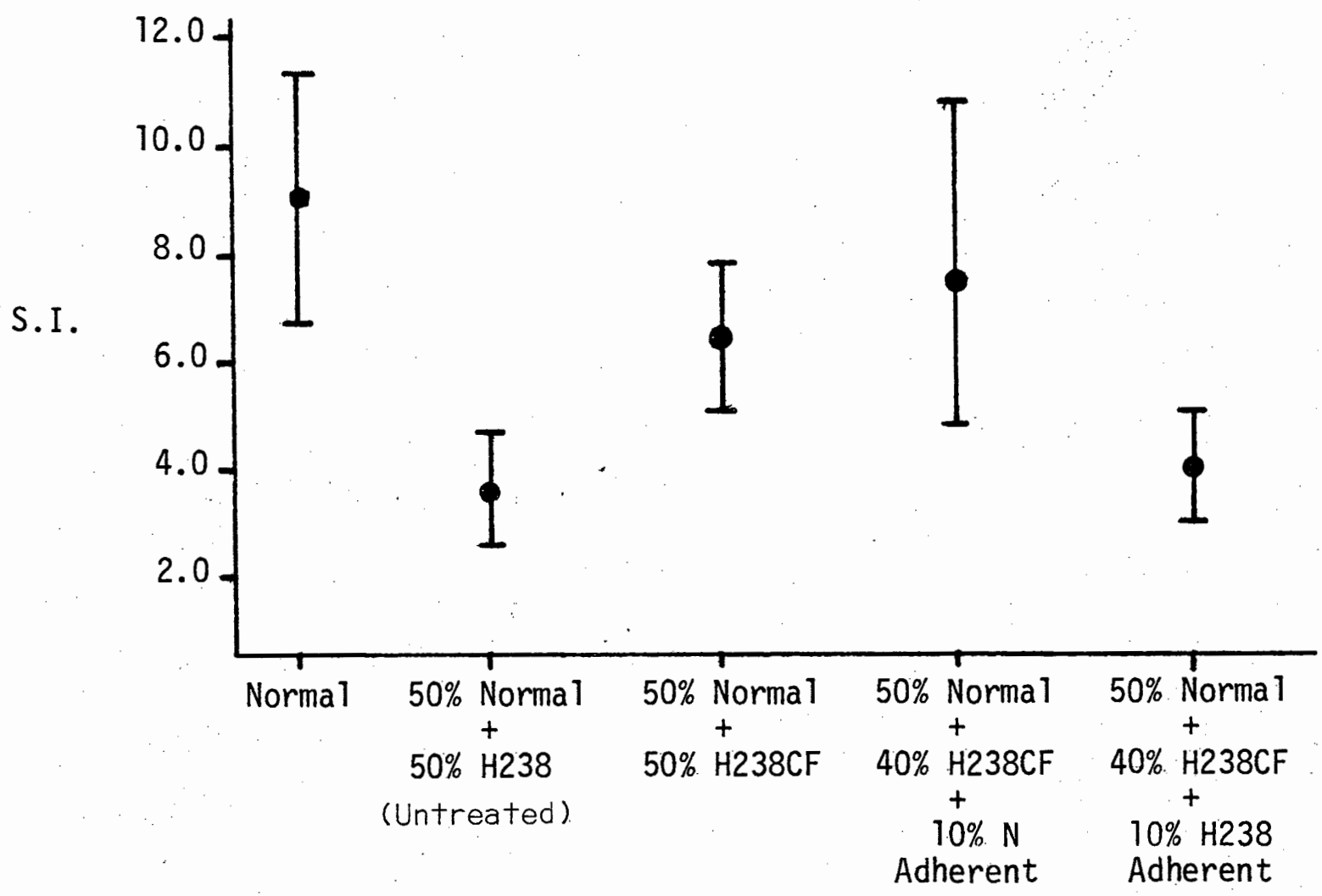


FIGURE 5: Effects of Sephadex G-10 Treatment and Reconstitution with Adherent Cells

in Spleen Cel1 Response to PHA Stimulation

in the $\# 5 \mathrm{~T}^{-}$System

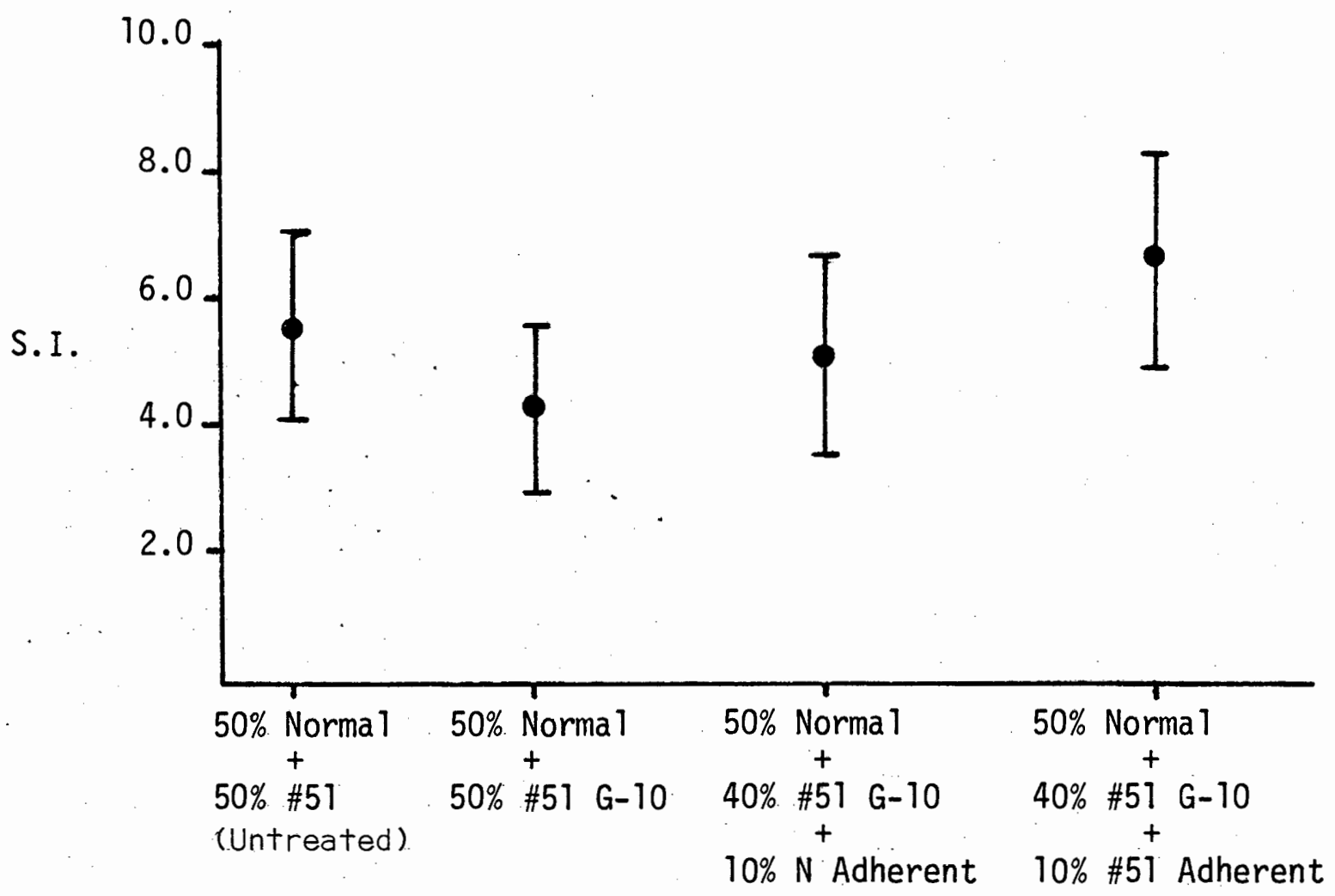


FIGURE 6: Effects of Carbonyl Iron Treatment and Reconstitution with Adherent Cells on Spleen Cel1 Response to PHA Stimulation in the \#51 System

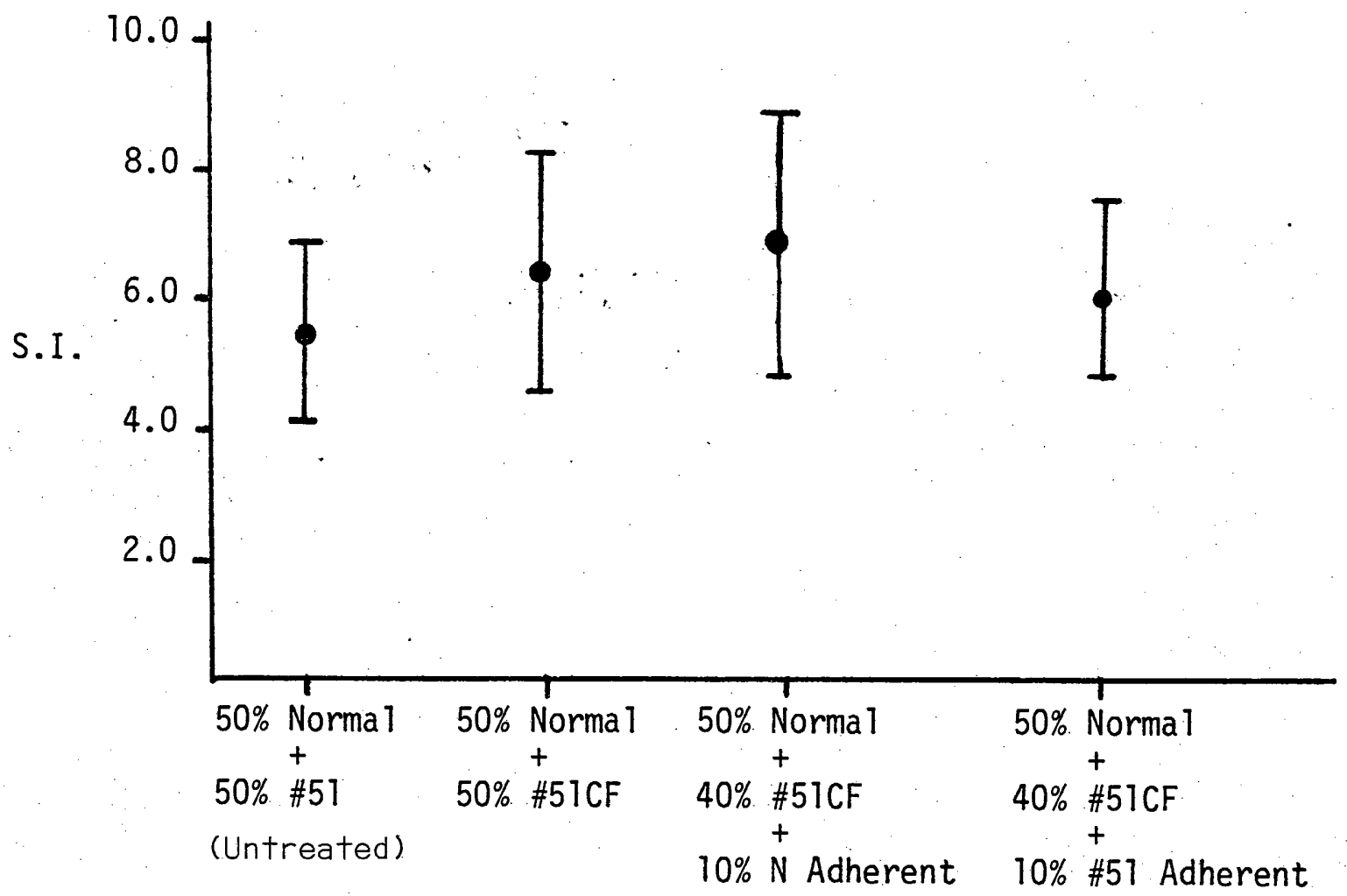


FIGURE 7: PHA Dose Response Curves

Spleen Cells from Normal and

H238 Ce11-Injected Mice

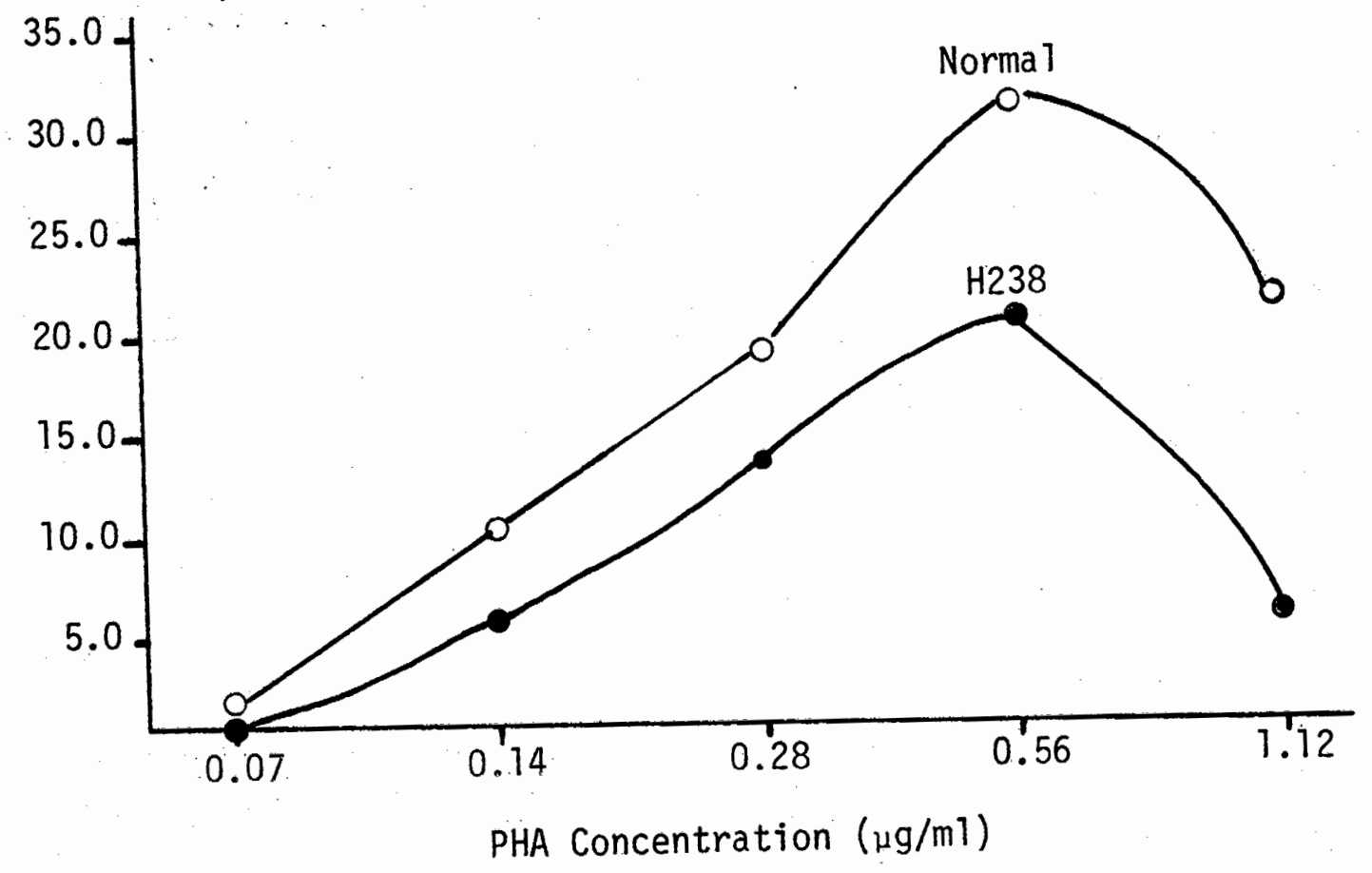


FIGURE 8: Effect of Reconstitution with Adherent Cells on Spleen Cell Response to PHA Stimulation in the H238 System

Normal $40 \%$ Sephadex G-10

Cells Nonadherent Cells
40\% Carbonyl iron

Nonphagocytic Cells

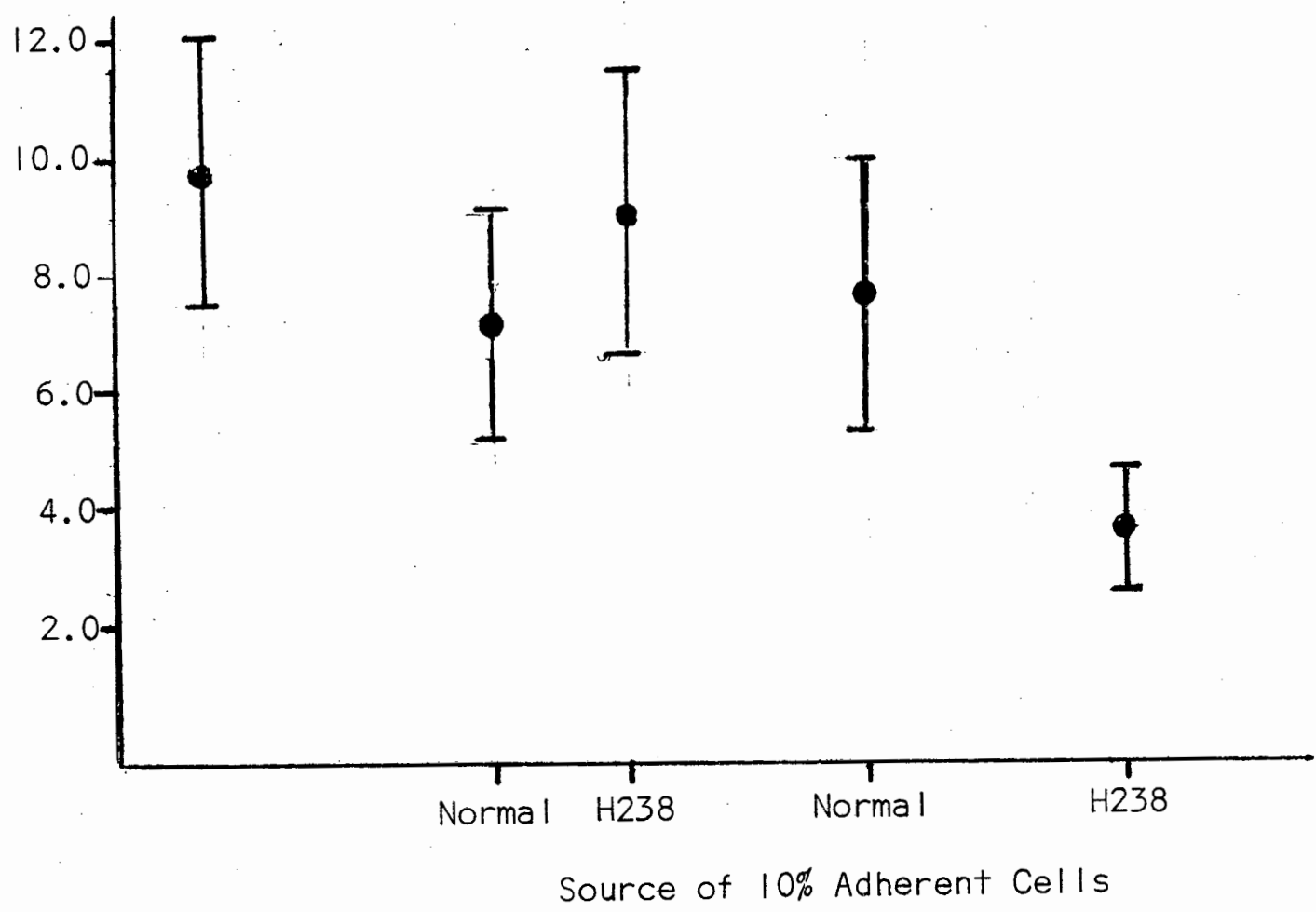


1. Anderson, S. A., Isakson, P. C., Pure, E., Muirhead, M., Uhr, J. W. and Vitetta, E. S. (1981) Immunosuppression in a Murine $B$ Cell Leukemia $\left(\mathrm{BCL}_{1}\right)$ : Role of an Adherent Cell in the Suppression of Primary in vitro Antibody Responses. J. Immunol. 126, 1603-1607.

2. Bluestone, J. A. and Lopez, C. (1979) Suppression of the Immune Response in Tumor-Bearing Mice. I. Response to Virus-producing Tumor Cells and Non-Virus-Producing Tumor Cells. J. Natl. Cancer Inst. 63, 1215-1220.

3. Boyd, A. L. and Orme, T. W. (1975) Transformation of Mouse Cells after Infection with Ultraviolet irradiatedinactivated herpes simplex virus Type 2. Int. J. Cancer, $16,526-538$.

4. Corbett, T. H., Griswold, D. P. Jr., Roberts, B. J., Peckham, J. C. and Schabel, F. M. Jr. (1975) Tumor Induction Relationships in Development of Transplantable Cancers of the Colon in Mice for Chemotherapy Assays, with a Note on Carcinogen Structure. Cancer Res., 35, 2.434-2439.

5. Dixon, W. F. and Massey, F. J. Jr. (1969) Introduction to Statistical Analysis, McGraw-Hill, New York, 328.

6. Eccles, S. A. and Alexander, P. (1974) Macrophage Content of Tumors in Relation to Metastatic Spread and Host Immune Reaction. Nature, 250, 667-669.

7. Eggers, A. E. and Wunderlich, J. R. (1975) Suppressor Cells in Tumor-Bearing Mice Capable of Nonspecific Blocking of in vivo Immunization against Transplant Antigens. J. Immunol., 114, 1554-1556.

8. Fauve, R. M., Hevin, B., Jacob, H., Gaillard, J. A. and Jacob, F. (1974) Antiinflammatory Effects of Murine Malignant Cells. Proc. Natl. Acad. Sci. USA, 71, 4052-4056.

9. Fisher, R. I. and Bostick-Bruton, F. (1982) Depressed T Cell Proliferative Responses in Hodgkin's Disease: Role of Monocyte-Mediated Suppression via Prostaglandins and Hydrogen Peroxide. J. Immunol., 129, 1770-1774.

10. Fisher, R. I., Vanhaelen, C., and Bostick, F. (1981) Increased Sensitivity to Normal Adherent Suppressor Cells in Untreated Advanced Hodgkin's Disease. Blood, $57,830-835$. 
11. Gabizon, A., Leibovich, S. J. and Goldman, R. (1980) Contrasting Effects of Activated and Nonactivated Macrophages and Macrophages from Tumor-Bearing Mice on Tumor Growth in vivo. J. Natl. Cancer Inst., 65, 913-920.

12. Garrigues, H. J., Romero, P., Hellström, I. and Hellström, K. E. (1981) Adherent Cells (Macrophages?) in Tumor-Bearing mice Suppress MLC Responses. Cell Immunol. $60,109-118$.

13. Gerson, J. M., Varesio, L. and Herberman, R. B. (1981) Systemic and in situ Natural Killer and Suppressor Cell Activities in Mice Bearing Progressively Growing Murine. Sarcoma-Virus-Induced-Tumors. Int. J. Cancer, 27, 243-248.

14. Gery, I. and Handschumacher, R. E. (1974) Potentiation of the $T$ Lymphocyte Response to Mitogens. III. Properties of the Mediator(s) from Adherent Cells. Cell Immuno.1., 11, 162-169.

15. Glaser, M., Kirchner, H. and Herberman, R. B. (1975) Inhibition of in Vitro Lymphoproliferative Responses to Tumor-associated Antigens by Suppressor Cells from Rats Bearing Progressively Growing Leukemia Virus-Induced Tumors. Int. J. Cancer, 16, 384-393.

16. Glaser, M., Kirchner, H., Holden, H. T. and Herberman, R. B. (1976) Inhibition of Cell-Mediated Cytotoxicity Against Tumor-Associated Antigens by Suppressor Cells from Tumor-Bearing Mice. J. Natl. Cancer Inst., 56, 865-867.

17. Glaser, M. (1980) Indomethacin-sensitive Suppressor Cells Regulate the Cell-mediated Cytotoxic Response to SV40-induced Tumor-associated Antigens in Mice. Eur. J. Immunol., 10, 489-495.

18. Gridley, D. S., Kettering, J. D., Garaza, C. D., Andres, M. L., Slater, J. M. and Nutter, R. L. (1982) Modification of herpes-2-transformed cell-induced Tumors in Mice Fed Different Sources of Protein, Fat, and Carbohydrates. Cancer Letters, 17, 161-173.

19. Herr, H. W. (1981) Adherent Suppressor Cells in the Blood of Patients with Bladder Cancer. J. Urology, 126, $457-460$. 
20. Hibbs, J. B. Jr. (1973) Macrophage Nonimmunological Recognition: Target Cell Factors Related to Contact Inhibition. Science, $180,868-870$.

21. Igarashi, T., Rodrigues, D. and Ting, C. (1979) Studies of the Mechanism for the Induction of in vivo Tumor Immunity. IV. Enhancement of the in vitro Generation of Secondary Cell-Mediated Cytotoxic Response by Normal Peritoneal Macrophages and their Culture Supernatants. $\mathrm{J}$. Immunol., 122, 1519-1527.

22. Iguchi, S., Ishii, Y., Yamaoka, H., Sato, N. and Kikuchi, K. (1981) Occurrence of Two Distinct Subpopulations of Suppressor Cells in Rats Bearing Chemically Induced Tumors. Neoplasma (Bratisl), 28, 51-58.

23. Jessup, J. M., Pellis, N. R. and Kahan, B. D. (1980) The Spleen as a Source of Nonspecific Suppressor. Cells in the Tumor-Bearing Mouse. J. Surg. Res., 28, 460-465.

24. Joshua, D. E., Humphrey, J. H., Grennan, D. and Brown, G. (1980) Immunosuppression in BALB/c mice bearing the Plasmacytoma TEPC-183: Massive Increase in Red Pulp Macrophages Induced by the Tumour. Immunology, 40, 223-228.

25. Kikuchi, Y., Hiramoto, R. N. and Ghanta, V. K. (1982) Mitogen Response of Peripheral Blood and Splenic Lymphocytes and Effect of 2-Mercaptoethanol in Tumor-Bearing Mice. Cancer Immunol. Immunother., 12, $225-230$.

26. Kirchner, H., Chused, T. M., Herberman, R. B., Holden, H. T. and Lavrin, D. H. (1974) Evidence of Suppressor Cell Activity in Spleens of Mice Bearing Primary Tumors Induced by Moloney Sarcoma Virus. J. Exp. Med., 139, 1473-1487.

27. Kirchner, H., Muchmore, A. V., Chused, T. M., Holden, H. T. and Herberman, R. B. (1975) Inhibition of Proliferation of Lymphoma Cells and Lymphocytes by Suppressor Cells from Spleens of Tumor-Bearing Mice. J. Immunol., 116, 206-210. 
28. Kumar, R. K., Lykke, A. W. J. and Penny, R. (1981) Immunosuppression Associated with SJL/J Murine Lymphoma. I. Suppression of Cell-Mediated Immune Responses after Tumor Transplantation. J. Natl. Cancer Inst., 67, 1269-1277.

29. Kusumoto, S. (1981) Cell-mediated Immunity in Cancer Patients with Special Reference to Lung Cancer. Nippon Acta Radio., 41, 792-803.

30. Laing, C. A. (1982) Kinetics of the Reactivity of Subpopulations of Spleen Cells of Mice Bearing Virus-Induced Mammary Tumors to Syngeneic Antigenic Extracts in vitro. Cancer Immunol. Immunother., 13, 98-104.

31. Lindahl-Kiessling, K. and Peterson, R. D. A. (1969) The Mechanism of Phytohemagglutin (PHA) Action. I. Mouse Spleen Cells in Short Term Culture. The Effect of Neonatal Exposure to Phytohemagglutinin. Exptl. Cell Research, 54, 231-236.

32. Ly, I. A. and Mishell, R. I. (1974) Separation of Mouse Spleen Cells by Passage through Columns of Sephadex G-10. J. Imm. Meth., 5, 239-247.

33. Matthews, N., Chalmers, P. J., Flannery, G. R. and Nairn, R. C. (1976) Characterization of Cytotoxic Spleen Cells and Effects of Serum Factors in a Syngeneic Rat Tumor System. Br. J. Cancer, 33, 279-289.

34. Mohge, M. V., Advani, S. H. and Gangal, S. G. (1981) Suppressive Effect of Adherent Mononuclear Cells from Peripheral Blood of Patients with Hodgkin's Disease on PHA Responsiveness. Indian J. Exp. Biol.,19, 1101-1106.

35. Nelson, M., Nelson, D. S. and Hopper, K. E. (1981) Inflammation and Tumor Growth $I$. Tumor Growth in Mice with Depressed Capacity to Mount Inflammatory Responses: Possible Role of Macrophages. Amer. J. Path., 104, 114-124.

36. Norman, S. J., Schardt, M. and Sorkin, E. (1981) Biphasic Depression of Macrophage Function after Tumor Transplantation. Int. J. Cancer,28, 185-190.

37. Nowell, P. C. (1960) Phytohemagglutinin: An Initiator of Mitosis in Cultures of Normal Human Leukocytes. Cancer Res., 20, 462-466. 
38. Nutter, R. L., Gridley, D. S., Slater, J. M. and McMillan, P. J. (1980) Responses of Mouse Spleen Morphology to the Growth of Subcutaneously Injected Virally Transformed Cells. Anat. Rec.,197, 363-368.

39. Nutter, R. L., Gridley, D. S., Kettering, J. D., Drexler, D. L. and Slater, J. M. (1982) Different Weekly Changes in Immune Responses in Virus-transformed Cell-injected Mice Fed Two Different Diets. Cancer Letters, 17, 175-185.

40. Nutter, R. L., Grialey, D. S., Kettering, J. D., Andres, M. L., Aprecio, R. M. and Slater, J. M. (1983) Modification of a Transplantable Colon Tumor and Immune Responses in Mice Fed Different Sources of Protein, Fat and Carbohydrates. Cancer Letters, 18,49-62.

41. Padarathsingh, M. L., Dean, J. H., Jerrells, T. R. and Law, L. W. (1981) Suppressor Cell Activity in Mice Bearing a Progressively Growing Simian Virus 40-Induced Sarcoma. Cancer Immunol. Immunother.,10, 75-85.

42. Peterson, W. J. (1982) Identification and Estimation of the Proportion of Limiting Cell Types Involved in the Phytohemagglutinin Response by Limiting Cell Dose-Response Analysis. Cell Immunol., 70, 260-270.

43. Pickel, K. and Hoffman, M. L. (1977) Suppressor T Cells Arising in Mice Undergoing a Graft-vs-Host Response. J. Immunol., 118, 653-656.

44. Pope, B. L., Whitney, R. B., Levy, J. G. and Kilburn, D. G. (1976) Suppressor Cells in the Spleens of TumorBearing Mice: Enrichment by Centrifugation on HypaqueFicoll and Characterization of the suppressor Population. J. Immunol., 116, 1342-1346.

45. Pope, B. L., Whitney, R. B. and Levy, J. G. (1978) Two Distinct Populations of Suppressor Cells in the Spleens of Mice Bearing Methylcholanthrene-Induced Tumors. J. Immunol., 120, 2033-2040.

46. Poupon, M., Kolb, J. and Lespinats, G. (1976) Evidence for Splenic Suppressor Cells in C3H/He, T-Cell Deprived $\mathrm{C} 3 \mathrm{H} / \mathrm{He}$, and Nude Mice Bearing a MethylcholanthreneInduced Fibrosarcoma. J. Natl. Cancer Inst., 57, 1241-1247. 
47. Robinson, M. L. and Wheelock, E. F. (1981) Identification of Macrophage-Mediated Cytolytic Activity as a Tumor Suppressive Mechanism during Maintenance of the L5178Y-Tumor Dormant state in DBA/2 Mice. J. Immunol, $126,673-679$.

48. Rosenstreich, D. L., Farrar, J. J. and Dougherty, S. (1976). Absolute Macrophage Dependency of $\mathrm{T}$ lymphocyte Activation by Mitogens. J. Immunol., 116, 131-139.

49. Schmidtke, J. R. and Hatfield, S. (1976) Activation of Purified Human Thymus-Derived (T) Cells by Mitogens. II. Monocyte-Macrophage Potentiation of Mitogen-Induced DNA Synthesis. J. Immunol.,116, 357-362.

50. Siegl, E., Guenther, I., Schulze, H. A. and Borck, J. (1981) Defects in Cell-mediated and Humoral Immunity in Tumor-bearing Mice: Evidence and Characterization of Suppressor Cells. Allerg. Immunol. (Leipz), 27, 153-161.

51. Spina, C. A., Dorey, F., Vescera, C., Brosman. S. and Fahey, J. L. (1981) Depression of the Generation of Cell-mediated Cytotoxicity by Macrophage-like Suppressor Cells in Bladder Carcinoma Patients. Cancer Res., 41, 4324-4330.

52. Takami, M. (1980) suppressor Cells Acting on Mitogeninduced Blastogenesis in Tumor-bearing Hosts. I. Suppressor Cells in the Spleens and Peripheral Blood of Tumor-Bearing Rats. J. Jpn. Orthop. Assoc., 54, 1553-1562.

53. Theis, G. A. (1981) Subpopulations of Suppressor Cells in Chickens Infected with Cells of a Transplantable Lymphoblastic Leukemia. Infect. Immun., 34, 526-534.

54. Treves, A. J., Horowitz, A., Biran, S., Brufman, G. and Fuks, A. (1981) Comparison of the Response to PHA and Suppressor Macrophage Function in Different Age Groups of Cancer Patients and Healthy Controls. Cancer, 48, 2606-2611.

55. Uede, T., Sato, O., Iguchi, S. and Kikuchi, K. (1981) Mechanism of Suppression on Cellular Immunity in Experimental Brain Tumor-bearing Rats. Neurol. Surg.,9, 503-508. 
56. Varesio, L., Giovarelli, M., Landolfo, S. and Fornia, G. (1979) Suppression of Proliferative Response and Lymphokine Production During the Progression of a Spontaneous Tumor. Cancer Res., 39, 4983-4988.

57. Veit, B. C. and Feldman, J. D. (1976) Altered Lymphocyte Functions in Rats Bearing Syngeneic Moloney Sarcoma Tumors. J. Immunol., 117, 646-654.

58. Veit, B. A. (1981) Variable Occurrence of Splenic Suppressor Macrophages in Normal and Tumor-inoculated Rats. Cell Immunol.,59, 367-377.

59. Webb, P. J., Brooks, C. J. and Baldwin, R. W. (1980) Macrophage-like Suppressor Cells in Rats. II. Evidence for a Quantitative Change in Tumour-Bearer Animals. Cell. Immunol.,52, 381-394.

60. Wood, D. D., Cameron, P. M., Poe, M. T. and Morris, C. A. (1976) Resolution of a Factor that Enhances the Antibody Response of $T$ Cell-Depleted Murine Splenocytes from Several Other Monocyte Products. Cell Immunol.,21, 88-96.

61. Yamagishi, J., Pellis, N. R. and Kahan, B. D. (1980) Effect of Splenectomy upon Tumor Growth: Characterization of Splenic Tumor-enchancing Cells in vivo. Surgery, 87, 655-661.

62. Yamagishi, H., Pellis, N. R., Macek, C. and Kahan, B. D. (1980) Changes in Spleen Morphology and Lymphoid Cell Activity During Tumor Progression. Eur. J. Cancer, 16, 1417-1426.

63. Zembala, M., Mytar, B., Popiela, T. and Asherson, G. L. (1977) Depressed in vitro Peripheral Blood Lymphocyte Response to Mitogens in Cancer Patients: The Role of Suppressor Cells. Int. J. Cancer, 19, 605-613. 